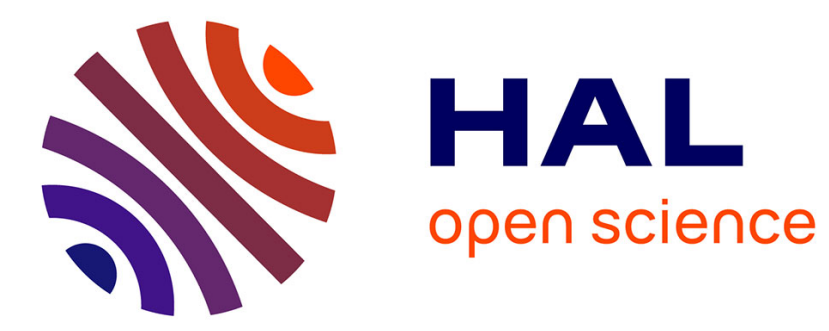

\title{
Trapping sylvatic triatominae (Reduviidae) in hollow trees
}

\author{
François Noireau, R. Flores, F. Vargas
}

\section{To cite this version:}

François Noireau, R. Flores, F. Vargas. Trapping sylvatic triatominae (Reduviidae) in hollow trees. Transactions of The Royal Society of Tropical Medicine and Hygiene, 1999, 93 (1), pp.13-14. 10.1016/S0035-9203(99)90161-X . hal-01256978

\section{HAL Id: hal-01256978 \\ https://hal.science/hal-01256978}

Submitted on 15 Jan 2016

HAL is a multi-disciplinary open access archive for the deposit and dissemination of scientific research documents, whether they are published or not. The documents may come from teaching and research institutions in France or abroad, or from public or private research centers.
L'archive ouverte pluridisciplinaire HAL, est destinée au dépôt et à la diffusion de documents scientifiques de niveau recherche, publiés ou non, émanant des établissements d'enseignement et de recherche français ou étrangers, des laboratoires publics ou privés.

\section{(이) $\$$}

Distributed under a Creative Commons Attribution - NonCommercial - NoDerivatives| 4.0 


\title{
Short Note
}

\section{Trapping sylvatic Triatominae (Reduviidae) in hollow trees}

\author{
F.. Noireau $1 *$, R. Flores ${ }^{2}$ and F. Vargas 2

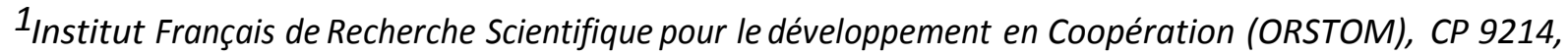 \\ La Paz, Bolivia; \\ 2Instituto Boliviano de Biología de Altura (IBBA), CP 641, La Paz, Bolivia \\ *Author for correspondence; phone +5912 227724, fax +591 2 225846, e-mail \\ noireauf@ceibo.entelnet.bo
}

Keywords: Triatoma infestans, Triatoma sordida, Triatoma guasayana, trapping, trees, Bolivia

Control of Chagas disease by the elimination of domestic vector species of Triatominae has been highly successful over vast areas of the Southern Cone countries where Triatoma infestans is the main domestic vector. This type of control is now being developed in the northen part of South America and in Central America where Rhodnius prolixus and T. dimidiata are the most significant vectors. Uncontrolled areas there are increasing numbers of reports of sylvatic species of Triatominae beginning to invade human dwellings. Consequently, research activities should focus on original sylvatic species adapting to peridomestic and domestic habitats. The entomological observations generated will assist in the adaptation of vector control strategies.

In the Chaco region of Bolivia the main sylvatic .candidate vectors are $T$. sordida and T. guasayana (NOIREAU et al., 1998). Recent observations have drawn attention to the existence of a sylvatic $T$. infestans 'dark morphs' population. The adults present chromatic (overall darker coloration with small yellow markings on the connexivum) and morphometric differences but isoenzymatic similarity with domestic $T$. infestans. This suggests that they form a separate 
population of the same species (NOIREAU et al., 1997). Nymphal instars of $T$. infestans 'dark morphs' have been collected from. hollow trees where they are probably living in association with wild rodents.

The collection of triatomines in their natural environment is laborious and timeconsuming. The light-trap has the disadvantage of capturing only starved adults of species attracted by light. Other methods include the inspection of a grea.t variety of potential ecotopes such as hollow trees. Various bait-traps have been designed to sample triatomines but they yield poor results (RABINOVICH et al., 1976; TONN et al., 1976; CARCAVALLO, 1985). This work reports the trial of a very simple trapping system to collect all instars of triatomines in hollow trees, a favourable ecotope for many triatomine species including $T$. sordida, $T$. guasayana, and $T$. infestans 'dark morphs'.

The surveyed area was La Choza ( $\left.18^{\circ} 34^{\prime} 516^{\prime \prime} \mathrm{S} ; 62^{\circ} 40^{\prime} 108^{\prime \prime} \mathrm{W}\right)$, an isolated site typical of the phytogeographical region of the Chaco, located on the route to Izozog (Cordillera Province, Department of Santa Cruz, Bolivia). The area is covered by dense and thick vegetation (elevation 4-6 m) consisting of hardwood trees with some reaching a height of $12 \mathrm{~m}$. The undergrowth consists predominantly, of thorn shrubs, bromeliads, and cacti. One hundred and forty-two traps comprising small plastic bottles $(9 \times 6 \mathrm{~cm})$ covered with double- coated adhesive tape and containing a mouse as bait were suspended by string in hollows of 82 trees located within a radius of $7 \mathrm{~km}$. They were placed for $8 \mathrm{~h}$ in the daytime or $15 \mathrm{~h}$ by night. Collected triatomines were identified by morphology (LENT \& WYGODZINSKY, 1979) and genetics (isoenzyme analysis) to discriminate between both $T$. sordida cryptic species occurring in the Chaco (named groups 1 and 2) and T. guasayana (NOIREAU et al., 1998).

From a total of 42 traps, 38 contained live triatomines which adhered to the tape $(26 \cdot 8 \%)$, while 2 traps presented only wings and/or legs of bugs. Captures were similar whether performed in the daytime or at night. T. infestans dark morphs was the predominant species $(60 \cdot 6 \%$ of the 71 triatomines captured), followed by T. sordida group $1(25 \cdot 3 \%)$, T. sordida group $2(9 \cdot 9 \%)$ and T. guasayana (4.2\%). The average number of triatomines captured by positive traps was $1.8 \pm$ 13. Most traps (76.3\%) contained only 1 species while $21 \cdot 1 \%$ contained 2 species and 1 trap (2.6\%) contained 3 species.

Twenty-nine (35.4\%) of 82 trees investigated were positive for triatomines, some trees being positive for several species. Eleven trees contained only T. infestans dark morphs (37.9\%) while $8(27 \cdot 6 \%)$ contained $T$. infestans and other species. Ten (34.5\%) contained T. sordida group 1 and/or T. sordida group 2 and/or T. guasayana. The majority of positive trees harboured nymphal instars ( $81.7 \%$ of the 71 captured triatomines were nymphs) and might be considered 
as breeding sites. The distribution by species was as follows: T. infestans, in 19 of the 29 positive trees (33 nymphs and 10 adults); T. sordida group 1, in 15 trees (17 nymphs and 1 adult); T. sordida group 2, in 5 trees ( 5 nymphs and 2 adults); and T.guasayana, in 3 trees ( 3 nymphs and no adults).

The bait-traps developed by TONN et al. (1976) consisted of wood-boxes divided into 2 parts, in one of which a chicken, rabbit, or mouse was placed. The same authors also modified the trap by wrapping it with adhesive tape. But many days of trapping were needed to capture a single specimen. In contrast, our results demonstrate that bait-traps can sample arboreal triatomines efficiently. The contrasting results may be due to the different behaviour of the triatomine species captured, and the small size of our traps which allowed them to be introduced into the hollow trees and not placed in the periphery of potential habitats as done byTONNetal. (1976).

\section{Acknowledgements}

This study received financial support from the United Nations Development Programme/World Bank/WHO Special Programme for Research and Training in Tropical Disease (grant 970182) and ECLAT. Our special thanks to J. Ireland for reviewing the manuscript.

\section{References}

Carcavallo, R. U. (1985). Técnicas de estudio de triatominos en ambiente silvestre. In: Factores Biológicos y Ecológicos en la Enfermedad de Chagas, Carcavallo, R.U., Rabinovich, J. E. \& Tonn R. J. (editors). Buenos Aires: OPS-ECO/MSAS- SNCH, volume 1, 49-52.

Lent, H. \& Wygodzinsky, P. (1979). Revision of the Triatominae (Hemiptera, Reduviidae), and their significance as vectors of Chagas disease. Bulletin of the American Museum of Natural History, 163, 127-520.

Noireau, F.,Flores, R., Gutierrez, T. \& Dujardin,J. P. (1997). Detection of sylvatic dark morphs of Triatoma infestans in the Bolivian Chaco. Memorias do Instituto Oswaldo Cruz, 92, 583584.

Noireau, F., Gutierrez, T., Zegarra, M., Flores, R., Brenière, F., Cardozo, L. \& Dujardin, J.-P. (1998). Cryptic speciation in Triatoma sordida (Hemiptera: Reduviidae) from the Bolivian Chaco. Tropical Medicine and International Health, 3, 364- 372.

Rabinovich, J. E., Carcavallo, R. U. \& Barretto, M. P. (1976). Ecologic methods: marking, trapping, and sampling for vector studies in the field. In: New Approaches in American Trypanosomiasis Research. Washington: Pan-American Health Organization, Scientific Publication no. 318, pp. 16-20. 
Tonn, R. J., Carcavallo, R. U., Ortega, R. \& Carrasquero, B. (1976). Métodos de estudio de triatominos en el medio silvestre. Boletín de la Dirección de Malariologia y Saneamiento Ambiental, 16, 146-152. 